\title{
STRATEGI GURU DALAM PEMBELAJARAN PAI PADA ANAK BERKEBUTUHAN KHUSUS
}

\author{
Wela Oktari 1) * \\ Hendra Harmi 2) \\ Deri Wanto ${ }^{3)}$ \\ 1,2,3 Program Studi Pendidikan Agama Islam \\ Institut Agama Islam Negeri (IAIN) Curup, Bengkulu \\ *E-mail: welaoktari4@gmail.com
}

\begin{abstract}
Every human being cannot choose whether he/she will be born normally or not. To be born normally or not is of Allah's decision. Every parent must realize this so that they will not regard their children born as individuals with special needs as disgrace and disaster. Such children deserve education and teaching because they are also given the potential by Allah to understand their needs to survive. How to educate them becomes an interesting issue to be studied. Thus, this study qualitatively addressed teachers' strategies in Islamic education learning for children with special needs in SLBN 1 Kepahiang, Bengkulu. The findings of this study exhibited that the teachers' strategies in Islamic Education learning for children with special needs in SLBN 1 Kepahiang were initiated by taking account of several aspects, namely: 1) service to students focused on the patterns of teachers' behavior in educational interactions at school; 2) curriculum adjustment; and 3) the implementation of learning by applying the methods of demonstration and habituation, especially for the materials of worshiping practices.
\end{abstract}

Keywords: Strategies, Islamic Education Learning, Children with Special Needs

\begin{abstract}
Absrak
Setiap manusia tidak dapat memilih bahwa ia akan lahir dalam keadaan sempurna maupun tidak. Terlahir sempurna maupun tidak merupakan ketentuan Allah. Setiap orang tua harus menyadari hal itu, agar mereka tidak menganggap bahwa anak terlahir sebagai individu yang berkebutuhan khusus sebagai aib dan musibah. Mereka layak memperoleh pendidikan dan pengajaran, karena merekapun diberi potensi oleh Allah untuk memahami kenutuhannya untuk bertahan hidup. Tentang bagaimana cara mendidik mereka menjadi persoalang yang menarik untuk diteliti, sehingga penelitian ini akan membahas secara kualitatif berkaitan dengan strategi guru dalam pembelejaran PAI kepada anak berkebutuhan khusus di SLBN 1 Kepaiang, Bengkulu. Adapun hasil penelitian ini memperoleh simpulan bahwa strategi guru dalam pembelajaran Pendidikan Agama Islam pada anak berkebutuhan khusus di SLBN 1 Kepahiang diawali dengan pertimbangan beberapa aspek yaitu: 1) pelayanan pada siswa yang terfokus pada pola prilaku guru dalam interaksi edukatif di sekolah; pada aspek, 2) aspek penyesuaian kurikulum; dan 3) aspek pelaksanaan pembelajaran dengan menggunakan metode demonstrasi dan pembiasaan terutama pada materi-materi praktek ibadah.
\end{abstract}

Kata kunci: Strategi, Pembelajaran Agama Islam, Anak Berkebutuhan Khusus

\section{PENDAHULUAN}

Salah dari tujuan pernikahan dalam Islam adalah meneruskan keturuan dengan harapan dapat menjadi kader-kader agama yang sehat secara fisik dan mentap serta berpengetahuian yang luas. Memiliki keturunan tersebut merupakan harapan utama 
bagi setiap pasangan suami istri yang baru menikah (Faradina, 2016; Matondang, 2014; Utami, 2015). Anak merupakan anugerah terindah yang diberikan oleh Allah SWT, dan kelahirannya selalu ditunggu-tunggu bagi orang tua. Kehadirannya merupakan kebahagiaan tiada tara yang tidak bisa dibandingankan dengan harta ataupun nyawa. Jika kelahiran anak membuat para perempuan merasa sempurna, maka bagi laki-laki merupakan sebuah keberhasilan yang membanggakan karena mendapat keturunan sebagai penerusnya kelak(Daheri \& Warsah, 2019; Warsah, 2018). Seperti dalam QS. al-Furqan ayat 74: “Dan orang orang yang berkata: "Ya Tuhan Kami, anugrahkanlah kepada Kami isteri-isteri Kami dan keturunan Kami sebagai penyenang hati (Kami), dan Jadikanlah Kami imam bagi orang-orang yang bertakwa"

Anak juga sebagai lambang pengikat cinta kasih antara kedua orang tuanya (Mantra, 2019; Mastra \& Adnyana, 2020; Nonci, 2019). Akan tetapi jika Allah SWT memberikan anak yang tidak sempurna baik secara fisik dan mental atau termasuk golongan anak berkebutuhan khusus (ABK). Tentu setiap orang tua akan sedih bercampur cemas takut bahwa anaknya tidak akan mampu menghadapi kehidupan dunia nyata dengan baik. Hal yang perlu dilakukan hanyalah pasrah, menerima, dan mendidiknya dengan ikhlas serta penuh kasih sayang.

Pengertian anak berkebutuhan khusus (ABK) menurut Heward adalah anak dengan karakteristik khusus yang berbeda dengan anak pada umumnya tanpa selalu menunjukan pada ketidakmampuan mental, emosi, atau fisik(Supriyatna \& Suwarni, 2017). Anak berkebutuhan khusus, apa pun jenis dan karakteristiknya, bukanlah suatu aib yang harus disembunyikan. "Anugerah yang tidak diinginkan" itu juga bukan merupakan suatu kehinaan sehingga orang yang bersangkutan harus mengurungnya dalam kamar tertutup dan tidak terjamah orang lain.

Anak berkebutuhan khusus merupakan sebutan bagi anak yang berkarakter berbeda dengan anak pada umumnya. Tidak selalu menunjukan ketidakmampuan mental, emosi, dan fisik.Anak berkebutuhan khusus memerlukan penanganan khusus, terutama dalam hal pendidikan. Berdasarkan pada "UUD 1945 Pasal 31 ayat (1) setiap warga negara berhak mendapatkan pengajaran". Landasan Yuridis inilah yang menjadi masyarakat memiliki hak yang sama dan seimbang untuk memperoleh pendidikan dan pengajaran yang layah untuk anak-anak mereka tidak terkecuali bagi anak berkebutuhan khusus. Malalui satu sistem pengajaran nasional yang diatur dengan undang-undang. Sehubungan dengan tuntutan konstitusi dimaksud, "Pemerintah 
berketetapan untuk membentuk lembaga yang bertanggungjawab pada usaha pencerdasan kehidupan bangsa"(Dewi, 2019; Hanur \& Avif, 2019; Jannah, 2017).

Menurut Undang-Undang sistem pendidikan nasional nomor 20 tahun 2003, "Pendidikan nasional berfungsi mengembangkan kemampuan dan membentuk watak serta peradapan bangsa yang bermartabat dalam rangka mencerdaskan kehidupan bangsa, bertujuan untuk berkembangnya potensi peserta didik agar menjadi manusia yang beriman dan bertakwa kepada tuhanyang maha Esa, berakhlak mulia, sehat, berilmu, cakap, kreatif, mandiri, dan menjadi warga negara yang demokrasi serta bertangung jawab"(Agustina et al., 2019; Hasyim \& Supardi, 2018). Disebutkan dalam pasal 32 ayat (1) yang berbunyi: "Pendidikan khusus merupakan pendidikan bagi peserta didik yang memiliki tingkat kesulitan dalam mengikuti proses pembelajaran karena kelainan fisik, emosional, mental, sosial, dan/atau memiliki kecerdasan dan bakat istimewa"(HAKIM, 2017; Setyawan, 2017; Yasir et al., 2017; Yunita et al., 2019). Dari ketentuan-ketentuan ini jelas menyebutkan bahwa anak-anak luar biasa, istilah yang digunakan untuk anak berkebutuhan khusus berhak mendapat pendidikan yang bermutu seperti anak-anak pada umumnya, tanpa menganggap sebelah mata.

Namun, dalam sistem pendidikan di Indonesia, selama ini belum mengakomodasi keberagaman. sehingga menyebabkan munculnya segmentasi lembaga pendidikan yang berdasar pada perbedaan agama, etnis, dan bahkan perbedaan kemampuan baik fisik maupun mental yang dimiliki oleh siswa. Segmentasi ini yang memisahkan dan mengkhususkan antara anak-anak yang normal dengan anakanak yang berkebutuhan khusus.

Anak-anak yang normal ditempatkan pada sekolah regular pada umumnya, sedangkan anak-anak berkebutuhan khusus ditempatkan pada sekolah khusus atau SLB (Sekolah Luar Biasa). Segmentasi lembaga pendidikan ini telah menghambat wawasan pendidikan yang lebih luas serta menghambat para siswa untuk dapat belajar menghormati realitas keberagaman dalam masyarakat Pendidikan inklusif dihadirkan untuk menjawab persoalan di atas, yang mana pendidikan inklusif mencoba memadukan dua objek pendidikan antara anak normal dengan anak berkebutuhan khusus dalam satu kelas.

Dalam pendidikan inklusif tentunya tidak terlepas dari pentingnya Pendidikan Agama Islam. Pendidikan Agama Islam dimaksudkan untuk meningkatkan potensi spiritual dan membentuk peserta didik agar menjadi manusia yang beriman dan 
bertaqwa kepada Allah SWT serta berakhlak mulia. Hal ini sesuai dengan tujuan Pendidikan Agama Islam itu sendiri yang bertujuan meningkatkan keimanan, pemahaman, penghayatan, dan pengalaman peserta didik tentang agama Islam sehingga menjadi manusia muslim beriman dan bertaqwa kepada Allah SWT serta berakhlak mulia dalam kehidupan pribadi, masyarakat, berbangsa, dan bernegara.

Pendidikan Agama Islam tidak hanya diberikan pada anak-anak yang normal saja, tetapi juga diberikan pada anak-anak berkebutuhan khusus, karena setiap manusia mempunyai hak yang sama di hadapan Allah SWT, seperti yang sudah dijelaskan dalam Q.S. An Nuur ayat 61: “Tidak ada halangan bagi orang buta, tidak (pula) bagi orang pincang, tidak (pula) bagi orang sakit, dan tidak (pula) bagi dirimu sendiri, makan (bersama-sama mereka) dirumah kamu sendiri atau di rumah bapak-bapakmu, dirumah ibu-ibumu, dirumah saudara- saudaramu yang laki-laki, di rumah saudaramu yang perempuan, di rumah saudara bapakmu yang laki-laki, dirumah saudara bapakmu yang perempuan, dirumah saudara ibumu yang laki-laki, di rumah saudara ibumu yang perempuan, di rumah yang kamu miliki kuncinya atau di rumah kawankawanmu. tidak ada halangan bagi kamu Makan bersama-sama mereka atau sendirian. Maka apabila kamu memasuki (suatu rumah dari) rumah-rumah (ini) hendaklah kamu memberi salam kepada (penghuninya yang berarti memberi salam) kepada dirimu sendiri, salam yang ditetapkan dari sisi Allah, yang diberi berkat lagi baik. Demikianlah Allah menjelaskan ayat-ayatnya (Nya) bagimu, agar kamu memahaminya".

Mengajarkan Pendidikan Agama Islam kepada peserta didik lebih sulit dari pada mengajarkan ilmu yang lain, karena Pendidikan Agama Islam mempunyai tujuan untuk meningkatkan keimanan, pemahaman, penghayatan dan pengalaman peserta didik tentang agama Islam sehingga menjadi manusia muslim yang beriman dan bertaqwa kepada Allah SWT serta berakhlak mulia dalam kehidupan pribadi, bermasyarakat, berbangsa dan bernegara (Munib, 2019). Kesulitan itu juga dipengaruhi karena dalam mengajarkan Pendidikan Agama Islam menyangkut perasaan dan menitik beratkan pada pribadi peserta didik, bukan intelektual semata. Pendidikan Agama Islam juga diorientasi kepada tiga ranah yang meliputi ranah kognitif, afektif, dan psikomotoris.

Dengan tingkat kesulitan yang berdasarkan pada orientasi dalam mengajarkan Pendidikan Agama Islam tersebut, menjadikan sebuah tantangan bagi guru saat mengajarkan Pendidikan Agama Islam. Apalagi peserta didik dalam satu kelas menggunakan pendidikan inklusif di mana peserta didik dipadukan antara anak 
normal dengan anak berkebutuhan khusus. Bisa dibayangkan betapa sulitnya seorang guru untuk mengkondisikan kelas, serta melaksanakan proses kegiatan belajar mengajar.

Dalam hal ini tentunya profesionalitas guru sangat diperlukan dan banyak hal yang perlu dipersiapkan, terutama strategi yang digunakan guru saat mengajarkan Pendidikan Agama Islam pada kelas inklusif. Strategi mempunyai pengertian suatu garis-garis besar haluan untuk bertindak dalam usaha mencapai sasaran yang telah ditentukan. Strategi yang baik akan terwujud jika elemen dalam struktur organisasi terjadi koordinasi dengan baik, membuat tema tentang apa yang akan dilakukan, melakukan identifikasi foktor pendukung sesuai dengan prinsip dan gagasan yang rasional agar program tadi dapat terlaksana dengan efisien dan efektif (Umam, 2017). Pengertian ini mempertegas bahwa strategi menjadi hal yang sangat penting karena dijadikan sebagai haluan dalam proses pembelajaran, karena tanpa adanya strategi yang tepat untuk digunakan pada sekolah inklusif maka tidak akan tercapai tujuan dari Pendidikan Agama Islam yang maksimal.

Pendidikan Agama Islam adalah usaha berupa bimbingan dan asuhan terhadap anak didik agar kelak setelah selesai pendidikannya dapat memahami dan mengamalkan ajaran agama Islam serta menjadikannya sebagai pandangan hidup (way of life). Pentingnya mempelajari ilmu agama ini bermakna luas, tidak memandang kondisi seseorang baik dia normal ataupun memiliki keterbatasan fisik, mental maupun perilaku. Anak berkebutuhan khusus juga berhak mendapatkan pendidikan. Amanat hak atas pendidikan bagi penyandang kelainan atau ketunaan ditetapkan dalam Undang Undang No 20 Tahun 2003 tentang Sistem Pendidikan Nasional Pasal 23 disebutkan bahwa: "pendidikan khusus (anak luar biasa) merupakan pendidikan bagi peserta didik yang memiliki kesulitan dalam mengikuti proses pembelajaran karena kelainan fisik, emosional, mental, sosial" (Erawati et al., 2017).

Meskipun sekolah tersebut belum masuk pada kategori inklusif, namun memiliki kelas inklusif, di mana anak berkebutuhan khusus yang bermacam-macam karakteristik. Tentu dalam hal ini sangat terasa tingkat kesulitan dalam proses pengajaran bagi guru terutama guru Pendidikan Agama Islam di SLBN 1 Kepahiang. Guru PAI dituntut untuk lebih memahami peserta didik yang bermacam-macam karakteristik (observasi, 23 Februari). Berangkat dari paparan masasalah di atas, mendorong peneliti untuk melakukan studi empirik bagaimana strategi guru dalam 
memberikan pembelajaran pendidikan agama Islam pada anak berkebutuhan khusus di SLBN 1 Kepahiang.

\section{METODE}

Penelitian ini menggunakan pendekatan kualitatif guna memperoleh informasi tentang strategi guru Pendidikan Agama Islam (PAI) dalam melaksakan tugasnya dalam proses pembelajaran di SLBN 1 Kepahiang(Anggito \& Setiawan, 2018). Tujuan penelitian ini ialah untuk membuat rumusan serta mengetahui strategi dan perlakuan guru terhadap anak berkebutuhan khusus dan juga untuk mengetahui faktor-faktor pendukung dan penghambat seorang guru PAI dalam memberikan pembelajaran pada anak berkebutuhan khusus Subjek dalam penelitian adalah guru PAI yang mengajarkan siswa/siswi di SLBN 1 Kepahiang Kemudian dokumentasi didapat dari data-data yang ada di sekolah SLBN 1 Kepahiang.

Jika dilihat dari tujuan akan dicapai dalam penelitian ini, maka analisis data yang bersifat kualitatif yang tidak bisa diukur dengan angka Data dikumpulkan melalui wawancara dan observasi. (Gumilang, 2016; Hadi, 2017; Hasanah, 2017). Adapun analisis data penelitian ini menggunakan pendekatan model interaktif (Miles et al., 2014). Peneliti menganalisis data berdasarkan empat elemen analisis. Pertama, peneliti melakukan pengumpulan data berbasis pada observasi dan wawancara terbuka. Selanjutnya, peneliti melakukan pemadatan data atau biasa dikenal dengan istilah reduksi data. Setelah data direduksi, peneliti menyajikan data. Dalam penelitian ini penyajian data diuraikan dalam bentuk narasi dan pada tahapan terakhir, peneliti menyimpulkan data.

\section{HASIL DAN PEMBAHASAN}

Paparan hasil penelitian yang didapatkan di lapangan tentang strategi guru dalam pembelajaran pada mata pelajaran Pendidikan Agama Islam di SLBN 1 Kepahiang yang terdiri dari dua aspek yaitu gambaran tentang implementasi pembelajaran dan strategi yang diterapkan oleh guru PAI.

\section{Gambaran tentang Implementasi kurikulum SLBN}

Hasil observasi di lapangan ditemukan beberapa data yang menyimpulkan bahwa dalam pengimplementasian kurikulum 2013 pada sekolah luar biasa tidak bisa sepenuhnya dilakukan, perlu dilakukan modifikasi. Modifikasi kurikulum 2013 yang dilakukan yang paling menonjol terdapat pada media pembelajaran, metode 
pembelajaran, dan penilaian. Dapat dilihat pada kuikulum 2013 tersebut adanya metode menalar, tentu saja untuk siswa berkebutuhan khusus itu tidak bisa dilakukan dilakukan seperti yang dilakukan kepada anak normal untuk itu digunakanlah media atau contoh nyata untuk membantu mereka (Observasi, 27 Februari 2020).

Menurut bapak kepala sekolah Anjang Daryono, S.Pd menjelaskan sebagai teori penerapan kurikulum bahwa "Impelementasi kurikulum 2013 dilakukan secara bertahap diawali dengan mengimplementasikan kurikulum pada satuan pendidikan umum atau reguler kemudian dilanjutkan pada pengimplementasian kurikulum pada satuan pendidikan khusus pada anak berkebutuhan khusus (ABK)”. Lebih lanjut dikatakan bahwa "strategi pelaksanaan kurikulum reguler disesuaikan dengan gradasi berat atau ringannya kondisi peserta didik mendapatkan banyak peran dalam pembelajaran mulai dari menentukan sendiri tema atau hal yang akan dipelajarinya, menentukan kesepakatan atau aturan kelas dan mengusulkan kegiatan yang akan dipelajari. Dengan begitu dapatnya tercipta lingkungan pembelajaran yang komunikatif, ramah, dan bersahabat. Implementasi kurikulum 2013 dilakukan secara bertahap, hal tersebut dilakukan berdasarkan peraturan dari Dinas Pendidikan (Wawancara, 27 Februari 2020).

Sementara penanaman nilai-nilai Islam di kelas anak berkebutuhan khusus sangat berbeda dengan kelas biasa, hal tersebut mendorong guru PAI untun menemukan pola pembelajaran yang bervariasi sesuai dengan karakteritik peserta didik. Apa lagi masih ditemukan peserta didik yang mempunyai minat yang rendah dalam mengikuti pelajaran sehingga berdampak pada rendahnya pemahaman pembalajaran pendidikan agama Islam sehingga jam pelajaran yang singkat dirasakan lama (Observasi 25 Februari 2020).

\section{Strategi guru dalam pembelajaran Agama Islam SLBN 1 Kepahiang}

Problem yang ditemui dalam proses pembelajaran di SLBN 1 Kepahiang, mendorong guru menciptakan kondisi tertentu agar peserta didik tumbuh motivasi dan minat untuk mengiikuti pembelajaran. Untuk mengatisipasi hal tersebut, dalam data hasil observasi dan wawancara di atas diperoleh jawaban tahapan-tahapan yang dilakukan oleh guru dalam pembelajaran PAI di SLBN 1 Kepahiang sebagai bagian dari strategi yang efektif. gambaran data hasil wawancara menunjukkan bahwa strategi yang dilakukan oleh guru PAI adalah sebagai berikut (wawancara, 27 Februari 2020:

\section{a. Aspek Pelayanan guru pada siswa}


1) Perilaku menunjukkan perasaan positif, yaitu perasaan peduli dan bertanggung jawab untuk memberikan bantuan pada anak berkebutuhan khusus

2) Perilaku beradaptasi dengan anak. Adaptasi dengan kondisi anak berkebutuhan khusus yang dimaksud berupa menyesuaikan program pembelajaran untuk anak berkebutuhan khusus. Perilaku memperhatikan dan mengakui inisiatif serta cara belajar anak secara individual akan memiliki dampak yang sangat besar bagi anak berkebutuhan khusus. Bagaimanapun juga anak berkebutuhan khusus merupakan anak yang memiliki perbedaan dari anak lain, sehingga program pembelajaran dan penanganan untuk anak berkebutuhan khusus perlu dilakukan adaptasi dengan karakteristik individual mereka.

3) Berbicara dengan anak, yaitu berinteraksi dalam bentuk mengajak anak untuk berpartisipasi dalam dialog mengenai isi tema yang akan dipelajari sehingga mereka terlibat secara pribadi.

4) Memberikan pujian dan penghargaan. Pujian dan penghargaan diberikan oleh guru kelas apabila anak mau berusaha dan mau bekerja sama atau mengikuti instruksi yang diberikan

5) Membantu anak untuk memfokuskan perhatiannya. Seorang guru yang baik hendaknya senantiasa memberikan saran bagi anak didiknya dan bersedia bekerja dengan mereka. Perhatian dan pengalaman bersama merupakan sebuah prasyarat untuk menjalin komunikasi yang berpengaruh bagi perkembangan anak berkebutuhan khusus.

6) Membuat pengalaman anak menjadi bermakna. Anak didik berkebutuhan khusus akan lebih memahami sesuatu apabila memiliki pengalaman yang bermakna. Hal ini dapat dilakukan dengan cara melibatkan anak berkebutuhan khusus secara langsung terhadap pembelajaran yang dilaksanakan.

7) Perilaku menjabarkan dan menjelaskan. Tugas lain seorang guru adalah membantu anak didiknya dalam mengaitkan materi yang mereka pelajari dengan mata pelajaran lain dan aktivitas akademik lainnya. Ini akan memberikan wawasan, membantu membentuk asosiasi, membantu anak mencapai "pengalaman nyata" yang lebih holistik, serta memancing keingintahuan dan motivasi untuk belajar. 
8) Membantu anak mencapai disiplin diri, yaitu membantu anak untuk mencapai ketaatan dan ketepatan pada suatu aturan yang dilakukan secara sadar tanpa adanya dorongan atau paksaan pihak lain.

Ibu Indriani sebagai salah seorang guru PAI SLBN 1 Kepahiang memberikan tanggapan bahwa memang masih banyak hal perlu ditingkatkan dalam memberikan proses pembelajaran pada anak berkebutuhan khusus, seperti wawasan dan pemahaman guru tentang penanganan dan pelaksaan program bimbingan khusus. Hal ini merupakan factor eksternal yang penting untuk ditingkatkan baik berupa keterampilan, pengetahuan, kecerdasan, dan kompetensi profesional guru perlu menjadi perhatian dari pemerintan (wawancara, 25 Februari 2020).

Sementara dalam konteks kondisi siswa di SLBN 1 kepahian, tergambar pada data hasil wawancara dengan kepala sekolah SLBN 1 Kepahiang bapak Anjang Daryono, S.Pd. ia mengungkapkan bahwa: "Sesuai dengan namanya sekolah luar biasa anak-anak kami sangatlah luar biasa memiliki karakter yang sangat berbeda pada anak pada umumnya. Banyak orang berpikir bahwa mereka itu tidak bisa apaapa padahal mereka itu mempunyai hak memperoleh pembelajaran terutama pada mata pelajaran pendidikan agama Islam.

Banyak orang berangapan mereka tidak bisa melakukan salat padahal kalau kita latih terus menerus dan sabar maka merekapun bisa walaupun membutukan waktu yang lama karena mereka berbeda pada anak yang normal sebab itulah kenapa kami bertekat untuk membuat anak-anak yang luar biasa ini sama seperti anak pada umumnya" (wawancara, 25 Februari 2020). Sama halnya dengan hasil wawancara dengan Ibu Indriani, S.Pd.I selaku guru Pendidikan Agama Islam mengemukakan bahwa: "Mereka adalah anak-anak yang istimewa sehinga perilakukan istimewa juga. Walaupun mereka dalam katagori berkebutuhan khusus tapi bagi saya mereka adalah anak-anak yang hebat (wawancara, 25 Februari 2020).

Dalam data hasil pengamatan penelitian di lapangan bahwa "setelah bel berbunyi setiap siswa masuk ruangan masing-masing dan ada juga siswa-siswi yang di antar oleh orang tuanya karena sebagian dari anak memiliki keterbatasan tersendiri, selanjutnya merekapun masing-masing kelas berdoa yang dipimpin oleh wali kelas agar kegiatan tersebut menjadi kebiasaan". Hal ini membuktikan walaupun sekolah mereka adalah sekolah luar biasa yang tertuju pada anak berkebutuhan khusus tapi mereka bertekat bahwa mereka sama seperti anak 
normal pada umumnya. Mereka memiliki hak yang sama untuk memperoleh pengetahaun di tengah keterbatasan fisik dan psikis yang mereka punya sehingga memiliki kesulitan tersendiri dalam menyerap pembelajaran apalagi dalam pembelajaran prakterk ibadah. Namun sekolah tetap optimis bisa mendidik anakanak luar biasa.

\section{b. Aspek Penerapan kurikulum}

Secara teoretik Sijabat, dalam (Isma, 2019) menjelaskan bahwa "anak berkebutuhan khusus (ABK) adalah anak yang mempunyai kelainan/penyimpangan dari kondisi rata-rata anak normal baik secara fisik, mental, intelektual, soisal maupun emosional. Anak berkebutuhan khusus adalah anak-anak yang memiliki gangguan atau ketidakmampuan dan anak-anak yang tergolong mempunyai bakat tersendiri dibandingkan dengan anak-anak normal". Anak berkebutuhan khusus adalah anak dengan karakteristik khusus yang berbeda dengan anak pada umumnya tanpa selalu menunjukkkan ketidakmampuan mental, emosi atau fisik. Dalam dunia pendidikan anak berkebutuhan khusus diklasifikasikan atas beberapa kelompok sesuai dengan jenis kelainan anak:

1. Anak tunanetra (partially seing and legally blind), anak yang mengalami hambatan pada penglihatan. Meskipun indra penglihatan penglihatannya bermasalah, namun intelegensi mereka masih dalam taraf normal.

2. Anak tunarungu, anak yang mengalami hambatan di bidang pendengaran. Mereka mengalami permasalahan pada telinga oleh sebab itu mereka mengalami kesulitan dalam berinteraksi dan bersosialilsasi dengan orang lain. Seseorang yang mengalami gangguan pendengaran yang meliputi seluruh gradasi ringan, sedang, berat, yang dalam hal ini dapat dikelompokkan menjadi dua golongan yaitu kurang dengar dan tuli.

3. Anak tunagrahita, anak tunagrahita addalah anak yangkecerdasannya dibawah ratarata anak normal ditandai oleh keterbatasan inteligensi serta kecakapan terhadap komunikasi sosial.

4. Anak tunadaksa, suatu keadaan rusak atau terganggunya sebagai akibat gangguan bentuk atau hambatan pada tulang, otot, dan sendi dalam fungsinya yang normal. 
5. Anak tunalaras, anak yang mengalami gangguan atau hambatan emosi dan kelainan tingkah laku sehingga kurang dapat menyesuaikan diri dengan baik baik terhadap lingkungan keluarga, sekolah, dan masyarakat.

6. Anak autisme, anak yang mengalami kelainan perkembangan sistem saraf pada sesorang yang dialami sejak lahir maupun sejak balita, mengalami masalah pada komunikasinnya dan tingkah laku.

7. Anak kesulitan belajar, anak yang inteligensi rata-rata atau diatas rata-rata tetapi mangalami kesulitan dalam bidang akademik tertentu yang disebabkan oleh faktor neurologis.

8. Anak ADHD (Attention Deficit Hyperactivity Disorder), suatu kondisi dimana anak telah terlihat atau menunjukkan sikap hiperaktif impulsif dan sementara itu ada gejala lain yang datang dengan jenis macam sifat dan sikap yang lain.

9. Anak berbakat (Giftedness and Special Talents) anak yang memiliki inteligensi diatas rata-rata anak normal, dan memiliki bakat khusus.

10. Anak tunaganda (Multiple Handicapped), anak yang memiliki kombinasi kelainan (baik dua jenis kelainan atau lebih) yang menyebabkan adanya masalah pendidikan yang serius.

Jadi ABK adalah anak yang mengalami kelainan dengan karakteristik khusus yang membedakannya dengan anak normal pada umumnya serta memerlukan pendidikan khusus sesuai dengan jenis kelainan yang dimilikinya. Perubahan yang terjadi pada kurikulum 2013 meliputi empat elemen, yaitu standar kompetensi, standar proses, standar isi, dan standar penilaian (Muchtar, 2018). Menurut padangan kepala sekolah SLBN 1 Kepahiang "tentu kurikulum bagi anak berkebutuhan khusus (ABK) tidak terlepas dari kurikulum yang ada.

Tujuan kurikulum anak berkebutuhan khusus sama juga halnya dengan kurikulum untuk anak normal lainnya yaitu sama-sama untuk memebentuk perilaku peserta didik. Namun ada sedikit perbedaan untuk anak berkebutuhan khusus ini (ABK) yaitu pada evaluasinya. Jadi pengembangan kurikulum 2013 untuk anak berkebutuhan khusus (ABK) disesuaikan dengan kemampuan anak dan jenis hambatan atau kekurangannya". Dengan kata lain penerapan kurikulum 2013 pada siswa berkebutuhan khusus perlu dikaji untuk memaksimalkan guna memaksimalkan potensi peserta didik melalui perubahan kurikulum 2013. (Wawancara, 27 Feberuari 2020). 


\section{c. Metode dan pengelolaan proses pembelajaran}

Dalam melaksanakan pembelajaran banyak metode yang dapat dilakukan dalam proses pembelajaran yang akan mendukung dan mempermudah proses pembelajaran menjadi lebih menarik dan mudah di pahami. Metode yang digunakan oleh guru dalam proses pembelajaran PAI adalah metode demonstrasi dan metote pembiasaan. Kolaborasi metode ini memperoleh hasil yang baik dan dapat difahami oleh siswa berkebutuah khusus. Data hasil wawancara menunjukkan bahwa metode ini yang tepat terutama pada materi praktek seingga pelaksanaan praktek ibadah berjalan dengan baik dan secara tidak langsung hal itu sebagai solusi dalam untuk memudahkan guru menanamkan nilai-nilai Islami pada siswa berkebutuhan khusus.

Melihat kehidupan sekarang ini yang makin tidak terarah, maka peran guru Pendidikan Agama Islam dalam mendidik anak membentuk nilai-nilai ibadah sehingga karakter anak-anak akan menjadi lebih baik dan akan terhindar dari perbuatan-perbauatan yang melanggar norma-norma agama. Dengan kata lain pembelajaran akan menjadi lebih menarik jika disampaikan dengan cara yang menarik juga sehingga pembelajaran akan mudah untuk dipahami. Paparan data tersebut menemukan gambaran bahwa penggunaan metode pembelajaran yang tepat SLBN 1 Kepahiang ini berdampak positif dan efektiv serta sangat membantu guru untuk menanamkan nilai-nilai Islam tanpa mengabaikan pembelajaran lainnya.

Pengelolaan pembelajaran harus disesuaikan dengan situasi dalam lingkungan pembelajaran, pembelajaran akan menjadi lebih menarik jika lingkungan pembelajaran itu mendukung proses pembelajaran sehingga proses pembelajaran akan menjadi lebih menarik karena kenyamanan dalam belajar akan menunjang proses pembelajaran. Oleh karena itu berdasarkan hasil wawancara dan observasi, sebelum memulai pelajaran guru PAI mengkondisikan terlebih dahulu lingkungan tempat belajar agar tidak mengganggu konsentrasi siswa. Simpulan data ini memberikan argumen bahwa proses pembelajaran dapat dipengaruhi oleh suasana lingkungan belajar. Karena ketika lingkungan tidak kondusif akan berimplikasi pada hilangnya konstrasi anak berkebutuhan khusus dalam menyerap informasi dari guru. 


\section{KESIMPULAN DAN SARAN}

\section{Kesimpulan}

Strategi guru dalam pembelajaran Pendidikan Agama Islam pada anak berkebutuhan khusus di SLBN 1 Kepahiang diawali dengan pertimbangan beberapa aspek. Seperti pelayanan pada siswa, aspek penerapan kurikulum dan aspek pelaksanaan pembelajaran. Pada aspek pelayanan, fokusnya adalah pola perilaku yang ditunjukkan kepada siswa, menunjukkan perasaan positif; beradaptasi dengan anak secara baik; Mengajak anak berkomunikasi dengan baik; memberikan pujian dan penghargaan; membantu anak untuk untuk selalu focus; berusaha membuat pembelajaran selalu bermakna dan pengalaman bagi anak enjadi bermakna dan lailain. Pada aspek kurikulum disesuaikan dengan kurikulum ada namun pada aspek evaluasi disesuaikan dengan kondisi anak. Pada aspek pelaksanaan pembelajaran, guru PAI menerapkan metode demonstrasi dan pembiasaan, metode ini sangat tepat apalagi berkaitan dengan materi-materi praktek ibadah.

\section{Saran}

Berkaitan dengan bebarapa temuan hasil penelitian, diharapkan kepada kepala sekolah untuk selalu mendorong para guru untuk meningkatkan kompetensi mereka terutama pada teknik pembelajaran anak berkebutuhan khusus. Apa lagi pada guru pendidikan Agama Islam, karena jika dilihat dari latar belakang pendidikan mereka tentu tidak ada bebal sedikitpun bagaimana menghadapi anak berkebutuhan khusus kecuali hanya berbekal pengalaman. Kepada guru PAI diharapkan dapat meningkatkan kompetensinya dengan banyak mengikuti pelatihan terutama untuk pembelajaran anak berkebutuhan khusus.

\section{DAFTAR PUSTAKA}

Agustina, L., Daharnis, D., \& Hariko, R. (2019). Peran Konselor dalam Meningkatkan Disiplin Siswa: Tinjauan Berdasarkan Persepsi Siswa. JURKAM: Jurnal Konseling Andi Matappa, 3(1), 15-22.

Anggito, A., \& Setiawan, J. (2018). Metodologi penelitian kualitatif. CV Jejak (Jejak Publisher).

Anggraini, F. L., Hanurawan, F., \& Hadi, S. (2017). Membangun Keterampilan Sosial Sebagai Pendidikan Karakter pada Kegiatan Ekstrakurikuler. Seminar Nasional Teknologi Pembelajaran Dan Pendidikan Dasar 2017, 975-982. 
Daheri, M., \& Warsah, I. (2019). Pendidikan Akhlak: Relasi antara Sekolah dengan Keluarga. At-Turats, 13(1), 3. https://doi.org/10.24260/at-turats.v13i1.1285

Dewi, K. Y. F. (2019). Pengajaran Bahasa Inggris Untuk Anak Luar Biasa (ALB). Daiwi Widya, 6(1).

Erawati, D., Dian, A. K., \& Nurwidiantoro, N. (2017). Manajemen Layanan Peserta Didik Inklusif di Kota Palangka Raya. Jurnal Studi Agama Dan Masyarakat, 13(2), 194218.

Faradina, N. (2016). Penerimaan diri pada orang tua yang memiliki anak berkebutuhan khusus. EJournal Psikologi, 4(4), 386-396.

Gumilang, G. S. (2016). Metode penelitian kualitatif dalam bidang bimbingan dan konseling. Jurnal Fokus Konseling, 2(2).

Hadi, S. (2017). Pemeriksaan Keabsahan Data Penelitian Kualitatif Pada Skripsi. Jurnal Ilmu Pendidikan, 22(1).

HAKIM, A. R. (2017). Memuliakan Anak Berkebutuhan Khusus Melalui Pendidikan Jasmani Adaptif. Jurnal Ilmiah Penjas (Penelitian, Pendidikan Dan Pengajaran), $3(1)$.

Hanur, B. S., \& Avif, S. (2019). Melayani dengan Hati: Menghapus Diskriminasi dan Segregesi antara Anak Reguler dengan Anak Berkebutuhan Khusus melalui Sekolah inklusif YBPK Kota Kediri. Jurnal Al-Hikmah, 6(2), 27-40.

Hasanah, H. (2017). Teknik-teknik observasi (sebuah alternatif metode pengumpulan data kualitatif ilmu-ilmu sosial). At-Taqaddum, 8(1), 21-46.

Hasyim, A., \& Supardi, S. (2018). Pengaruh Kepemimpinan Kepala Sekolah Dan Disiplin Kerja Guru Terhadap Kinerja Guru di Madrasah Tsanawiyah Negeri Muara Kelingi. Jurnal Interprof, 4(1), 97-116.

Irvan, M., \& Jauhari, M. N. (2018). Implementasi Pendidikan Inklusif Sebagai Perubahan Paradigma Pendidikan Di Indonesia. Buana Pendidikan: Jurnal Fakultas Keguruan Dan Ilmu Pendidikan, 14(26), 175-187.

Isma, M. L. (2019). Implementasi Kurikulum 2013 di SLB Untuk Anak Berkebutuhan Khusus.

Jannah, M. (2017). Problema Guru Pembimbing Khusus Dalam Penyelenggaraan Program Pembelajaran Individual Bagi Anak Berkebutuhan Khusus di SD N 14 Koto Panjang. Jurnal Penelitian Pendidikan Khusus, 4(3).

Lukitasari, S. W., Sulasmono, B. S., \& Iriani, A. (2017). Evaluasi Implementasi Kebijakan Pendidikan Inklusi. Kelola: Jurnal Manajemen Pendidikan, 4(2), 121-134. 
Mantra, I. G. P. (2019). Adopsi Merupakan Cara Pemberian Status Hukum terhadap Anak Luar Kawin di Desa Pakraman Bukit Tumpeng Kecamatan Selemadeg Barat Kabupaten Tabanan. Vyavahara Duta: Jurnal Ilmiah Ilmu Agama dan Ilmu Hukum, 13(2), 1-8.

Mastra, I. W., \& Adnyana, I. B. G. B. (2020). Peran Lingkungan Membentuk Generasi Muda Cerdas, Berkualitas dan Berbudi Pekerti Luhur. Widyadari: Jurnal Pendidikan, 21(1).

Matondang, A. (2014). Faktor-faktor yang mengakibatkan perceraian dalam perkawinan. JPPUMA Jurnal Ilmu Pemerintahan Dan Sosial Politik Universitas Medan Area, 2(2), 141-150.

Miles, M. B., Huberman, A. M., \& Saldana, J. (2014). Qualitative data analysis: A methods sourcebook. SAGE Publications, Inc.

Muchtar, A. D. (2018). Implementasi Kurikulum Pai 2013 Pada Anak Berkebutuhan Khusus di SMPLB Bhakti Kencana Yogyakarta. Edumaspul: Jurnal Pendidikan, 2(1), 70-78.

Munib, A. (2019). Kontribusi Pendidikan Agama Islam Dalam Pembentukan Kepribadian Siswa di SMK Az-Zubaer Larangan Tokol Pamekasan. Al-Ulum Jurnal Pemikiran Dan Penelitian Ke Islaman, 6(2), 11-20.

Nonci, M. H. (2019). Pembentukan Karakter Anak Melalui Keteladanan. Sosioreligius, $4(2)$.

Setyawan, D. A. W. (2017). Problematika Pelaksanaan Pendidikan Jasmani di Sekolah Berkebutuhan Khusus. Seminar Nasional Pendidikan Olahraga, 1(1), 205-214.

Supriyatna, T., \& Suwarni, S. (2017). Perancangan dan Implementasi Sistem Informasi Pemantauan Perkembangan Anak Berkebutuhan Khusus pada Sekolah Luar Biasa Abdi Pratama. Jurnal Teknologi Informasi, 3(2), 17.

Umam, M. K. (2017). Strategi Alternatif Memajukan Lembaga Pendidikan Islam di Pedesaan Berbasis Sekolah Excellent Perspektif Kompetitif Kotemporer. Proceedings of Annual Conference for Muslim Scholars, Seri 2, 769-776.

Umami, F. N. (2016). Permasalahan dalam Pengelolaan Pendidikan Inklusif di Sekolah Dasar Negeri Piyaman III Kecamatan Wonosari Kabupaten Gunungkidul. Hanata Widya, 5(4).

Utami, F. T. (2015). Penyesuaian diri remaja putri yang menikah muda. Psikis: Jurnal Psikologi Islami, 1(1), 11-21.

Warsah, I. (2018). Pendidikan keluarga Muslim di Tengah Masyarakat Multi-Agama: Antara Sikap Keagamaandan Toleransi (Studi di Desa Suro Bali KepahiangBengkulu). Edukasia: Jurnal Penelitian Pendidikan Islam, 13(1), 1-24. 
Yasir, M., Suarman, S., \& Gusnardi, G. (2017). Analisis Tingkat Kepuasan Siswa dan Motivasi dalam Pembelajaran Kelompok (Cooperative Learning) dan Kaitannya dengan Hasil Belajar Akuntansi di Smklabor Binaan Fkip Unri Pekanbaru. PEKBIS (Jurnal Pendidikan Ekonomi Dan Bisnis), 9(2), 77-90.

Yunita, E. I., Suneki, S., \& Wakhyudin, H. (2019). Manajemen Pendidikan Inklusi dalam Proses Pembelajaran dan Penanganan Guru Terhadap Anak Berkebutuhan Khusus. International Journal of Elementary Education, 3(3), 267-274. 